\title{
The Increase in Length of Infants Who Were Given the Complementary Feeding Mixed of Ripe Awak Bananas Flour and Soybean Sprouts
}

\author{
Jumirah $^{1}$, Albiner Siagian ${ }^{2}$, Zulhaida Lubis ${ }^{3}$, and Posman Sibuea ${ }^{1}$ \\ ${ }^{1}$ Doctoral Programe School of Public Health Faculty University of North Sumatera, Medan, Indonesia \\ jumirah@usu.ac.id \\ ${ }^{2}$ Professor of Public Health Faculty, University of North Sumatera, Medan, Indonesia \\ albiner sgneyahoo.com \\ ${ }^{3}$ Lecturer of Public Health Faculty, University of North Sumatera, Medan, Indonesia \\ idaulinas@gmail.com \\ ${ }^{4}$ Professor of Agriculture Faculty, Catholic University of St. Thomas, North Sumatera, Medan, Indonesia \\ posmandust.ac.id
}

\begin{abstract}
Growth disorders in children under five can occur since the age of 6 months. one of the strategies to tackle the problem is through complementary feeding. Ripe awak bananas has been used as baby food since long time ago, so it's worth developed into complementary feeding. The purpose of study was to know the increaase in length of infants who were given the complementary feeding mixed of ripe awak bananas flour and soybean sprouts. Research done by quasy experimental non equivalent control group design, i.e. giving the complementary feeding for three months, using samples of 75 infants age 6 to 9 months, which were divided into three groups. The each group was given complementary feeding: ripe awak bananas flour, a mixture ripe awak bananas flour and soy sprouts, and the complementary feeding family (control). The results showed that the average increase in length of infants who were given complementary feeding ripe Awak bananas flour and a mixture ripe Awak bananas flour and soy sprouts was higher than control groups. But, the average increase in length of infants who were given a mixture ripe Awak bananas and soy sprouts was highest among the other groups. Concluded that the complementary feeding mixed of ripe Awak bananas flour and soy sprouts can be used as an alternative to prevention of stunting in children under five.
\end{abstract}

Keywords - complementary feeding, ripe Awak bananas flour, soy sprout, the increase in length of infants

\section{INTRODUCTION}

Good nutrition, especially in the first years of life give a lifetime benefits in health, education and productivity. Conversely, malnutrition at an early stage of life the child has physical consequences such as stunting and intellectual property for the long term.

Based on the results of the monitoring of the nutritional status by 2015 , amounting to $29 \%$ of under five years old children in Indonesia were stunting [1]. Although the figure is lower than the result of Riskesdas [2] in 2013 that is equal to $37.2 \%$, but according to WHO criteria which figures stunting exceeds $20 \%$, then Indonesia is still facing a public health problem. While in North Sumatera showed higher numbers, according to Riskesdas 2013 [2] found figures of about $43 \%$ and according to the results of the monitoring of the nutritional status by 2015 found amounted to $33.2 \%$. From the results of the survey of the malnutrition existence study in Medan in 2011 [3], found the growth disorder based on index of length for age by $43.8 \%$ in children aged 9 to 11 months.

Ramakrishnan et al., [4] suggests stunting can be prevented through the provision complementary feeding from ages 6 to 24 months of the first children's lives. The study results of Sunaryo [5], showed that were given complementary feeding with the addition of L-glutamine have an increase in length better than the control group and were given complementary feeding without the addition of Lglutamine. Furthermore, she is said that greater number of complementary feeding consumed by infants will give 3.8 more influence on the increase in length of the infants.

Thus, improved complementary feeding should be a top priority to meet the nutritional needs of infants 
up to the age of two years, because an important role in preventing death and increasing the growth and development of children in Indonesia. Complementary feeding improvements should ideally have to be aligned with the availability of local food ingredients are cheap and easy to obtain, as well as in accordance with the customs or culture of the local community.

The practice of giving complementary feeding form of rice porridge and ripe Awak bananas is a tradition which is still applicable in most communities, but both rice porridge and ripe Awak bananas as well as the shape of its alloy has a low protein content.

The research development of coplementary feeding used a mixture of ripe awak bananas flour and soy sprouts, it can increase the composition of a number of nutrients that are needed infants, especially protein content, and have organoleptic characteristics that can be received well by the baby. Researchers assumed complementary feeding mixed of ripe Awak bananas flour and soybean sprouts can increase the growth of baby based on the increase in length.

The results of this research are expected to be applied to the nutrition improvement program on the first 1000 days of life with targets are infants ages 612 months particularly from poor families. This is very important and should be a priority of the program, because the growth disorders in children are generally already occurred since the age of 6 months.

\section{METHOD}

This research used quasy experimental non equivalent control group design, i.e. the provision of complementary feeding which formulated and has been tested for nutrient content and acceptability. Complementary feeding was given for three months with an interval of awarding two days once and the day was done twice each as much as 25 grams. Prior to intervention, researchers offer an explanation and request the willingness of mothers who have infants ages 6-9 months to become partners for activities that are declared with the signing of inform's concern.

This study used a sample of 75 infants aged 6-9 months, were divided into three groups: the first group was given complementary feeding ripe Awak bananas flour (Formula A), the second group was given complementary feeding mixed of ripe Awak bananas flour and flour of soy sprouts 2:1 (Formula B), and the third as a control group that was given complementary feeding family.

The measurement of the length of the infants was done at the time before and after the intervention of each month using the length scale with a scale measuring $1 \mathrm{~mm}$.

During the research, complementary feeding was given through cooperation with the cadres of 'posyandu' (integrated community health service) in the local area for any period of 14 days of consumption accompanied by monitoring of giving complementary feeding to the infants by their mother. Data analysed using Kruskal Wallis test.

\section{RESULTS}

\section{A. The Increase in Length of Infants.}

The average value of the length of infants at the time before and after the intervention, and the average increase in the length of the infants in each group are shown in Table 1. In Table 1 it can be seen that the awarding of the complementary feeding mixed of ripe Awak bananas flour with soy sprouts showed the highest increase in length of infants compared to the other two groups.

TABLE I

AVERAGE OF LENGTH OF INFANTS BEFORE AND AFTER THE INTERVENTION AND ITS ASCENSION

\begin{tabular}{|l|c|c|c|}
\hline \multirow{2}{*}{$\begin{array}{c}\text { The group } \\
\text { of infants }\end{array}$} & \multicolumn{3}{|c|}{ Length of infants (cm) } \\
\cline { 2 - 4 } & $\begin{array}{c}\text { Before the } \\
\text { intervention }\end{array}$ & $\begin{array}{c}\text { After the } \\
\text { intervention }\end{array}$ & $\begin{array}{c}\text { Increase in } \\
\text { length }\end{array}$ \\
\hline Formula A & $68,49 \pm 3,04$ & $72,48 \pm 2,84$ & $3,99 \pm 0,27$ \\
Formula B & $67,41 \pm 3,18$ & $71,53 \pm 3,20$ & $4,12 \pm 0,29$ \\
Control & $67,94 \pm 3,25$ & $71,84 \pm 3,26$ & $3,90 \pm 0,47$ \\
\hline
\end{tabular}

\section{B. Infant's Growth Based on the Ratio of Increase in Length.}

The value of the ratio of increase in length of infants is calculated based on the ratio between the increase in length of infants measurement results with the median value increase in length standards differentiated according to age and gender [6]. Data processing results of the average value of the ratio of increase in length of infants in each group are shown in Table 2. 
TABLE II

THE AVERAGE VALUE OF THE RATIO OF INCREASE IN LENGTH OF INFANTS AFTER PERFORMED INTERVENTION.

\begin{tabular}{|l|c|c|c|}
\hline \multirow{2}{*}{$\begin{array}{c}\text { The group } \\
\text { of infants }\end{array}$} & \multicolumn{3}{|c|}{ Increases in length of infants (cm) } \\
\cline { 2 - 4 } & $\begin{array}{c}\text { Increases in } \\
\text { length }\end{array}$ & $\begin{array}{c}\text { Median } \\
\text { increases in } \\
\text { length }\end{array}$ & $\begin{array}{c}\text { Ratio of } \\
\text { increases in } \\
\text { length }\end{array}$ \\
\hline Formula A & $3,99 \pm 0,27$ & $4,152 \pm 0,238$ & 0,97 \\
Formula B & $4,12 \pm 0,29$ & $4,180 \pm 0,915$ & 0,99 \\
Control & $3,90 \pm 0,47$ & $4,236 \pm 0,196$ & 0,92 \\
\hline
\end{tabular}

In Table 2 it can be seen the higests average value of the ratio of length increase in the group of infants who were given complementary feeding Formula B i.e.amounting to 0.99 , subsequently followed by the group of infants who were given complementary feeding Formula A that is of 0.97 .

Based on the results of normality and homogeneity test data ratio of increase in length of infants, it was assumed that the data were normally distributed $(\mathrm{P}>$ $0.05)$, and the variance was not homogeneous ( $\mathrm{P}$ $<0.05)$. From the results of the analysis using the Kruskal Wallis test retrieved value $X^{2}$ of 12.050 and $\mathrm{P} 0.002$, which means there was a difference between the ratio of the increase in length of infants among the third group. The results of further analysis by Mann Whitney Test against the value of the ratio of increase in length of infants among the group who were given complementary feeding Formula A or Formula B with the control group, obtained respectively $\mathrm{P}$ value of 0.008 and 0.003 , which means the ratio of the increase in length of infants in the group given complementary feeding Formula A or Formula B differ significantly with the ratio of increase in length of infants in control group $(\mathrm{P}<$ $0.05)$.

The results of the analysis of the test of the difference between the ratio of the increase in length of infants of the group who were given complementary feeding Formula $\mathrm{A}$ with a given complenetary feeding Formula $\mathrm{B}$, the $\mathrm{P}$ value obtained of 0.099 , which mean there was no difference in the ratio of the increase in length of infants in both groups.

\section{Infant's Growth by Length/Age (L/A) Index.}

Data average of Zscore L/A index of infants before and after the interventions provision of complementary feeding, is shown in Table 3. The average value of Zscore L/A index the third group of infants prior to intervention are at a position -0.42 to $-0,06$.

TABLE III

THE AVERAGE VALUE ZSKOR L/A INDEX BEFORE AND AFTER THE INTERVENTION.

\begin{tabular}{|l|c|c|c|}
\hline \multirow{2}{*}{$\begin{array}{l}\text { Group of } \\
\text { Infants }\end{array}$} & \multicolumn{3}{|c|}{ Average value Zskor L/A Indeks } \\
\cline { 2 - 4 } & $\begin{array}{c}\text { Before } \\
\text { Intervention }\end{array}$ & $\begin{array}{c}\text { After } \\
\text { Intervention }\end{array}$ & $\begin{array}{c}\text { The change in } \\
\text { Zscore after } \\
\text { intervention }\end{array}$ \\
\hline Formula A & $-0,085 \pm 1,073$ & $-0,152 \pm-0,152$ & $-0,067$ \\
Formula B & $-0,424 \pm 1,660$ & $-0,374 \pm 1,580$ & 0,049 \\
Control & $-0,061 \pm 1,502$ & $-0,151 \pm 1,401$ & $-0,090$ \\
\hline
\end{tabular}

Kruskal Wallis test analysis results in Table 4 indicate that the change in the average value of $\mathrm{Z}$ score L/A index among the three groups of infants differed significantly. Based on the Mann Whitney test, proving that changes in the value of $\mathrm{Z}$ score group infants fed Formula B is significantly different from the change in value of $Z$ score groups of infants fed Formula A and the control groups $(\mathrm{P}<0,05)$.

TABLE IV

RESUlts OF THE KRUSKAL WALLIS TEST AND MANN WHITNEY AGAINST THE CHANGE IN VALUE OF ZSKOR L/A INDEX AFTER INTERVENTION.

\begin{tabular}{|l|c|c|c|}
\hline Group of infants & $\begin{array}{c}\text { The change in } \\
\text { value of } \\
\text { Zscore after } \\
\text { intervention }\end{array}$ & $\begin{array}{c}\text { Kruskal } \\
\text { Wallis } \\
\text { Test (P) }\end{array}$ & $\begin{array}{c}\text { Mann } \\
\text { Whitney } \\
\text { Test (P) }\end{array}$ \\
\hline Formula A & $-0,0672$ & & \\
Formula B & 0,0492 & 0,010 & - \\
\cline { 3 - 4 } Control & $-0,0896$ & & 0,290 \\
\hline Formula A vs Control & & 0,028 \\
Formula B vs Control & & 0,030 \\
\hline
\end{tabular}

\section{DISCUSSION}

Growth disturbances may occur throughout the life of infants. The research of Riviera and Ruel [7] in Guatemala, showed impaired toddler growth of $19-34 \%$ in the first $0-3$ months of life, $12-19 \%$ at age 3-6 months, $12-25 \%$ at age 6-9 months and $40-80 \%$ at the age of 9-12 months. Research results Prahesti [8] in Semarang, found a growth disorder occurring around the age of 6-12 months.

The results showed the average value of the increase in length on the infant groups intervened with the awarding of the complementary feeding mixed of ripe Awak banana flour and soy sprouts 
$(4.12 \mathrm{~cm})$ higher than the group that intervened with the complementary feeding mixed of ripe Awak bananas flour without soy sprouts $(3.99 \mathrm{~cm})$ or control group $(3.90 \mathrm{~cm})$, although the length of infants in the Group given complementary feeding mixed of ripe awak bananas flour and soy sprouts appears to be lower than the other two groups at the time prior to the intervention.

Likewise, if seen from the average value of the ratio of the increase in length of infants after the intervention, it turns on a group of infants who were given complementary feeding formula $\mathrm{B}$ was taller than the other two groups namely of 0.99 , in the group given complementary feeding without soy sprouts 0.97 and 0.92 in the control group.

Based on this it can be argued that the complementary feeding mixed of ripe awak bananas flour and soy sprouts give influence on the increase in length of infant is best compared with the kind of complementary feeding mixed of ripe awak bananas flour without soy sprouts and complementary feeding family.

The results of this analysis demonstrated through Kruskal Wallis statistical tests that showed significant differences among the three groups of infants $(\mathrm{P}<0.05)$, and the Mann Whitney test that showed giving complementary feeding mixed of ripe awak bananas flour and soy sprouts give better effect (value $\mathrm{P}$ 0.003) than the complementary feeding mixed of ripe awak bananas flour without soy sprouts (P 0.008) against the ratio increase in length of infants.

If paying attention to the results of the analysis on the growth of infants based on the value of the Zscore index L/A as shown in Table 3 and Table 4, it can be postulated that the average value of $\mathrm{Z}$ score on the group of infants who were given complementary feeding mixed of ripe awak bananas flour and soy sprouts experienced a rise of -0.42 be 0.37 or going on a hike of 0.05 .

Not so on the group of infants who were given complementary feeding mixed of ripe awak bananas without soy flour or in the control group, even though the infant's length increased but the value of $\mathrm{Z}$ score decreased respectively by 0.07 (from -0.09 into -0.15) and 0.09 (from -0.06 into -0.15).

Based on the foregoing, it can be explained that the value of the $\mathrm{Z}$-score index length/age on the group of infants who were given complementary feeding ripe awak bananas flour mix with soy sprouts have a tendency to approach zero point while the $\mathrm{Z}$ score index length/age on the group of infants who were given complementary feeding ripe awak bananas flour without soy sprouts or infants control group have a tendency away from zero point that would eventually lead to stunting.

The results of this study in accordance with the concept that has been said by Dewey and AduAfarwuah [9] that the quality of the complementary feeding may modify the relationship between the quantity of complementary feeding and linear growth. In this case can be expressed that modification of complementary feeding mixed of ripe awak bananas flour with soy sprouts can improve the quality of complementary feeding.

Judging from the aspect of nutrient composition, the complementary feeding mixed of ripe awak bananas flour with soy sprouts contains nutrients better than complementary feeding mixed of ripe banana flour without soy sprouts, especially the composition of proteins and amino acids. Additionally, based on acceptance test against infants do before interventions, by observing the baby's response when fed the complementary feeding show good acceptance of response. Thus in turn can affect the quantity of nutrients consumed by infants.

In addition, the ripe awak bananas flour and flour of soy sprouts each contains inulin, fructooligo saccharides (FOS) and galactooligo saccharides (GOS) which can act as a prebiotic. Components prebiotics contained in the complementary feeding can increase the absorption of some minerals in baby's digestive tract and may also serve to avoid the babies from disorders of infectious diseases, especially diseases of digestive disorders that often occur in infancy, so it will simultaneously affect the baby's growth is mainly the length of baby.

Age babies between 6 to 12 months is still a period of growth which is exceptionally fast, so in case of insufficient intake of nutrients- specially nutrients needed to support the growth process such as protein that contains a number of essensial amino acidsduring this period will quickly affect the infant's growth. 
In society at large, giving complementary feeding is still based on the experience of the family earlier as the provision of rice porridge, bananas ('awak' bananas and 'barangan' bananas or 'chicken' bananas ), a mixture of rice mushy with awak bananas, rice steamed with or without a mixture of vegetables or side dishes, and complementary feeding manufacturer. It often happens, when babies are given the complementary feeding, the frequency of breastfeeding is reduced. Because understanding in society, solid foods can make the babies sleep in peace, not fast hungry and rarely fussy, so that the mother can do other household routine work.

The fact a lot of going on, babies who were given complementary feeding family physically have relatively normal body weight even tend to be fat at first, but it is not always the case with the length of infants which a linear growth. It would be possible, when monitoring the growth of the baby in growth monitoring is done to weight gain alone without being accompanied by monitoring the increase in body length. Such conditions will remain a factor causing the high prevalence of stunting in children under five in Indonesia. According to UNICEF [10], nutritional deficiencies during the period of 1000 days of life of children can reduce the ability to fight and survive the disease, can interfere with their social and mental capacities. Stunting associated with developmental problems and is often is irreversible. A child who is stunted is likely to experience poor health and poor performance throughout its life. The findings are then used as the basis of many discussions of strategy overcoming the problem of nutrition, health and economies around the world, especially for poor countries and emerging [11].

The influence of the giving of the complementary feeding towards the growth and development of the brain and cognitive function is believed to be a positive impact. The results of studies conducted Pollitt et al., [12] in Guatemala, namely energy-rich foods i.e. granting of $682 \mathrm{KJ}$ and $11.5 \mathrm{~g}$ protein during prenatal and 24 months posnatal shows a test score, numerical knowledge, reading and language skills taller than those who received low-energy food that is of $246 \mathrm{KJ}$.

Results of research conducted Sunaryo [5] in Bogor, namely the administration of L-glutamine in the formulation of complementary feeding in infants 6 months for 3 months affect the profile of immunity and the length of infants better than infants given complementary feeding formula without Lglutamine and complementary feeding control.

Referring to the results of these studies, which describes the role of L-glutamine to the immune profile and the length of infants, it can be argued that the provision of complementary feeding interventions are formulated using ripe awak bananas flour and flour of soy sprouts have influence on the increase in length of infants. Because of the results of the analysis of amino acid composition that has been done on previous research showing the content of L-glutamine is the most (2.65\%) among the amino acid composition of the other, while the complementary feeding ripe awak bananas flour amounting to $1.32 \%$.

A longitudinal study about the growth of babies who were given complementary feeding manufacturer (blended food) and non-manufacturer (local food) in the Gowa conducted by Baso [13], showed that the complementary feeding manufacturer which was given to poor families can fix the increase in weight and length.

Results of research Astari et al., [14], showed that the quality of complementary feeding in infants whose normal growth was more diverse than in children who stunting, and in terms of the quantity of contribution of nutrient intake of complementary feeding in the group of normal children was higher than the groups of children stunting.

Consumption of complementary feeding more dominant influence the adequacy of energy and nutrients children aged 6-12 months compared with consumption of breastmilk so that consumption of low complementary feeding was a factor that caused the low intake of energy and nutrients and can lead to the occurrence of stunting.

\section{CONCLUSIONS AND SUGGESTIONS}

The increase in length of infants who were given the complementary feeding mixed of ripe awak bananas flour with soy sprouts for three months was better than the increase in the length of the infants was given complementary feeding mixed of ripe awak bananas flour without soy sprouts or the complementary feeding family. 
The increase in length of babies who were given complementary feeding mixed of ripe awak bananas flour and soy sprouts followed by a rise in the value of the Z-score index length for age, thus is expected to prevent growth disorders in the form of stunting in infancy.

\section{REFERENCES}

[1] Data and information centre of the Ministry of Health of the Republic of Indonesia. Infodatin: Under Five Years Children Stunting Situation. The Ministry of Health of the Republic of Indonesia, Jakarta, 2016

[2] Health Research and Development Agency of the Ministry of Health of Republic of Indonesia. Basic Health Research (RISKESDAS) 2013. The Ministry of Health of the Republic of Indonesia, Jakarta, 2013

[3] The Government's research and development agency of Medan City. Study of existence of Malnutrition in the City of Medan. The Government's Research and Development Agency of the Medan City, 2011

[4] Ramakrishnan, Usha, P. Nguyen, and R. Martorell. Effects of Micronutrients on Growth of Children under 5 Years of Age: Metaanalyses of Single and Multiple Nutrient Interventions, American Journal of Clinical Nutrition. Vol. 89, No. 1, pp. 191-203, 2009

[5] Sunaryo, Endang s. The Influence of the Giving of the L-glutamin on Restorer Complemtary Feeding against Quality Proteins, Profile of Cellular Immunity, and the Growth of Babies 6 Months Who are Having Underweight. Dissertation. Agriculture Institute of Bogor . Bogor, 2004.

[6] World Health Organization. WHO Child Growth Standards: Methods and Development: Growth Velocity Based On Weight, Height, and Head Circumference, 2009. Acces on 8 Pebruari 2010 at Http://www. Who. Int/Childgrowth/Standards/Velocity,.
[7] Riviera, J. and Ruel, M.T. Growth Retardation Starts in the First Three Months of Life Among Rural Guatemalan Children. Eur J Clin Nutr. Vol. 51(2):92-96, 1997.

[8] Prahesti, Amy, 2001. The relationship of nutritional parenting with growth faltering in children aged 0-12 months (study at Kecamatan Sumowono in Kabupaten Semarang in 2001). Graduate thesis. Diponegoro University. Acces at: http://www.fkm. undip.ac.id. June 10th, 2010.

[9] Dewey KG, Adu-Afarwuah S,. Systematic review of the efficacy and effectiveness of complementary feeding interventions in developing countries. Maternal \& Child Nutrition;4(Suppl 1):24-85, 2008.

[10] UNICEF. Tracking Progress in Maternal and Child Nutrition. New York, NY: United Nations Children's Fund. 2009.

[11] UNICEF-WFP-WHO. Asia-Pacific Regional Workshop on the Reduction of Stunting through Improvement of Complementary Feeding and Maternal Nutrition, 2010. Available at: http://www.unicef.org/eapro/Workshop

Report ReductionOfStunting 2010-06-7 FINAL.pdf

[12] Pollitt, E., K. S. Gorman, P. Engle, R. Martorell, and J. A. Rivera. Early supplementary feeding and cognition: Effects over two decades. Monographs of the Society for Research in Child Development, Serial No. 235, 58 (7), 1993

[13] Baso, M. Longitudinal Study of Infant's Growth were Given Blended Food and Local Food. Thesis. Agriculture Institute of Bogor. Bogor, 2007.

[14] Astari Lita Dwi, Amini Nasoetion,Cesilia Meti Dwiriani, 2006. The Relationshif of Consumption of Breastmilk and Complementary Feeding as Well as the Incidence of Stunting Children Aged 6-12 Months in Kabupaten Bogor. Media Gizi Keluarga. Vol. 30 No. 1: 1523, 2006. 